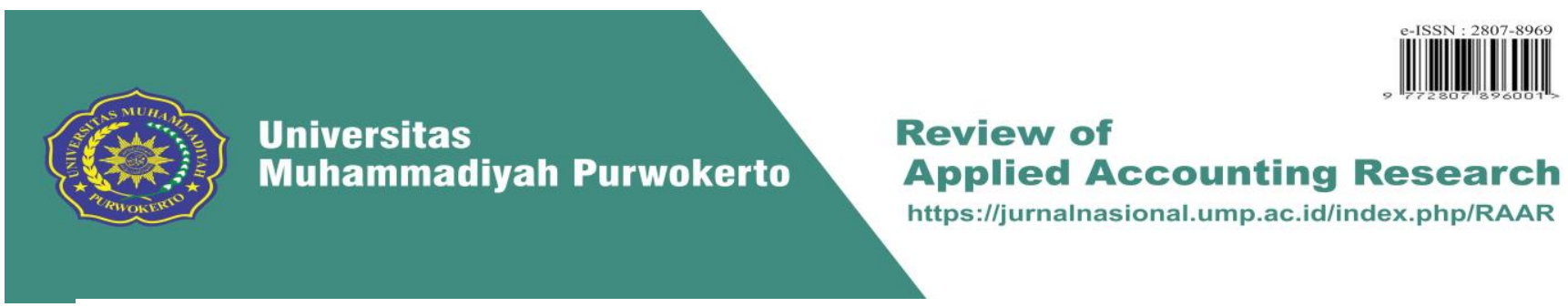

\title{
PROSEDUR PENCAIRAN DANA SANTUNAN ASURANSI KECELAKAAN TERHADAP KORBAN KECELAKAAN MENINGGAL DUNIA PADA PT.JASA RAHARJA (PERSERO) PURWOKERTO
}

\author{
Reza Aurora Fani*, Hardiyanto Wibowo
}

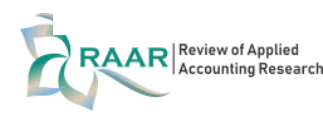

Affiliation:

Accounting Department, Universitas Muhammadiyah Purwokerto, Indonesia

*Correspondence: rezaazzuhri1998@gmail.com

Article Process:

Submitted:

January 23, 2021

Reviewed:

January 30, 2021

Revised:

February 25, 2021

Accepted:

February 25, 2021

Published:

February 28, 2021

\section{Citation:}

Aurora Fani, R., \& Wibowo, H. (2021). Prosedur Pencairan Dana Santunan Asuransi Kecelakaan Terhadap Korban Kecelakaan Meninggal Dunia Pada PT Jasa Raharja (Persero) Purwokerto. Review of Applied Accounting Research, 2(2), 48-65.

\section{Office Address:}

Jl. K.H. Ahmad Dahlan, Dukuhwaluh, Kec.

Kembaran, Kabupaten

Banyumas, Jawa Tengah 53182.

e-ISSN : 2807-8969

\begin{abstract}
ABSTRAK
Sistem Pengendalian Intern Dana Reses dimulai dari Tugas Akhir ini merupakan laporan hasil Praktek Kerja Lapangan yang dilakukan di PT Jasa Raharja (Persero) Purwokerto. Tujuan dari Tugas Akhir ini adalah untuk mengetahui, memahami dan memahami Tata Cara Pencairan Dana Santunan Asuransi Kecelakaan Bagi Korban Kecelakaan Meninggal Dunia di PT. Jasa Raharja (Persero) Purwokerto. Metode pengumpulan data menggunakan Metode Observasi, Metode Dokumentasi dan Metode Wawancara. Dari hasil observasi dapat disimpulkan bahwa Tata Cara Pencairan Dana Santunan Asuransi Kecelakaan Bagi Korban Meninggal Dunia di PT. Jasa Raharja (Persero) Purwokerto telah dapat menerapkan unsur-unsur dalam sistem akuntansi yaitu formulir pengajuan kompensasi, jurnal, bukti transaksi yang dapat memudahkan pengelolaan perusahaan. PT. Jasa Raharja (Persero) juga telah menerapkan beberapa unsur dalam pengendalian intern yaitu adanya struktur organisasi yang memisahkan tanggung jawab fungsional secara tegas dan mampu menerapkan sistem akuntansi yang baik yang dapat berguna untuk pengawasan harta kekayaan perusahaan.
\end{abstract}

Kata kunci: Tata Cara Pencairan Dana, Asuransi

\begin{abstract}
The Recess Fund Internal Control System starts from the This Final Project is a report on the result of Field Work Practices conducted at PT Jasa Raharja (Persero) Purwokerto. The purpose of this Final Project is to find out, understand and understand the Procedure for Disbursement of Accident Insurance Compensation Funds for Death Accident Victims at PT. Jasa Raharja (Persero) Purwokerto. Data collection methods use the Observation Method, Documentation Method and Interview Method. From the observations it can be concluded that the Procedure for Disbursement of Accident Insurance Compensation Fund Funds for Death Victims at PT. Jasa Raharja (Persero) Purwokerto has been able to apply the elements in the accounting system, namely the compensation submission form, journal, proof of transactions that can facilitate the management of the company. PT. Jasa Raharja (Persero) has also implemented several elements in an internal control, namely the existence of an organizational structure that separates functional responsibilities in a strict manner and is able to implement a good accounting system that can be useful for supervision of company property.
\end{abstract}

Keyword: Procedure For Disbursing Funds, Insurance 


\section{PENDAHULUAN}

Segala aktivitas kegiatan manusia untuk memenuhi kebutuhannya salah satunya adalah tersedianya alat transportasi, sehingga membuat orang semakin mudah bepergian dari satu tempat ke tempat yang lain dengan waktu yang begitu singkat. Pada hakekatnya keadaan ini sangat menunjang pertumbuhan pembangunan khususnya di bidang insfrastruktur dan ekonomi, namun demikian tidak dapat dihindari dampak kemajuan tersebut yakni timbulnya kecelakaan yang diakibatkan oleh kendaraan bermotor maupun kendaraan angkutan lainnya.

Dari situlah pemerintah berupaya melindungi masyarakat dengan cara memberikan jaminan sosial berupa dana santunan asuransi kepada masyarakat yang menjadi korban kecelakaan lalu lintas.

Pelaksanaan pemberian jaminan tersebut tertuang dalam undang- undang No. 33 tahun 1964 tentang dana pertanggungan wajib kecelakaanpenumpang dengan peraturan pemerintah No. 17 tahun 1965 dan undang- undang No. 34 tahun 1964 tentang dana kecelakaan lalu lintas jalan raya dengan peraturan pemerintah No. 18 tahun 1985. Untuk menjalankan kedua undang-undang tersebut di atas oleh pemerintah dipercaya kepada badan usahamilik negara (BUMN) dibawah departemen PT. Asuransi Jasa Raharja.

PT. Jasa Raharja (Persero) adalah perusahaan milik negara yang bergerak dalam bidang asuransi sosial serta memberikan jasa kepada korban kecelakaan lalu lintas, sebagaimana yang dituangkan dalam undang-undang No. 33 dan undang-undang No. 34 tahun 1964 yang berbunyi. Untuk memberikan perlindungan kepada masyarakat yang menjadi korban kecelakaan lalu lintas jalan.

Pelayanan yang baik kepada masyarakat yang mengalami musibah kecelakaan lalu lintas jalan adalah merupakan perwujudan dari fungsi,visi danmisi yang diemban oleh perusahaan PT. Jasa Raharja (Persero) sebagai pengelola undang-undang No. 33 dan undang-undang No. 23 tahun 1964Juncto peralihan pemerintahan No. 17 dan 18 tahun 1965.

Undang-undang No.33 Tahun 1964 memuat peraturan-peraturan mengenai iuran wajib tiap penumpang yang sah dari kendaraan bermotor umum, yang harus di penuhi melalui pengusaha/pemilik kendaraan angkutan yang bersangkutan guna menutup keuangan yang disebabkan oleh kecelakaan penumpang dalam perjalanan. Jika undang-undang No. 34 Tahun 1964 memuat peraturan-peraturan yang khusus diajukan kepada kecelakaan lalulintas jalan, yang jelasnya ialah akibat bahwa kepada setiap orang yang menjadi korban mati atau cacat akibat kecelakan yang disebabkan oleh suatu alat angkutan diluar lalu lintas dan angkutan jalan akan diberikan dana santunan atau ganti kerugian. Dana ganti kerugian tersebut bersumber dari dana iuran wajib yang dibayar oleh setiap pengusaha angkutan umum setiap tahunnya dengan pengecualian kendaraan ambulance, kereta jenazah dan pemadam kebakaran.

Untuk memperoleh santunan terebut, PT. Jasa Raharja (Persero) memiliki prosedur pembayaran klaim yang telah diatur oleh perusahaan. Korban atau ahli waris yang ingin mengajukan klaim terlebih dahulu harus melengkapi syarat pengajuan klaim yang telah ditetapkan. Setelah syarat dilengkapi, Korban atau ahli waris mengajukan berkas ke bagian pelayanan klaim. Nantinya penanggung jawab bagian pelayanan akan melakukan pengecekan untuk memastikan kelengkapan berkas. Tidak hanya pengecekan kelengkapan berkas, untuk 
memastikan kebenaran kejadian dan agar tidak ada penipuan penangung jawab bagian administrasi pelayanan juga akan melakukan survey/penelitian kasus tersebut.

Dalam prakteknya, pembayaran klaim asuransi seringkali terbenturbanyak kendala sehingga pembayaran klaim tersebut sulit diterima oleh pihak korban/ahli waris. Salah satu kendala yang ditemukan adalah tidak lengkapnya berkas. Ketidaklengkapan tersebut diakibatkan ketidaktahuan pihak korban atau ahli waris terkait syarat-syarat yang mesti diajukan serta kurangnya sosialisasi dari pihak PT. Jasa Raharja (Persero) kepada masyarakat luas. Dilain hal, pihak instansi pemerintah seperti kelurahan atau kecamatan yang mengeluarkan KTP, surat keterangan ahli waris, kartu keluarga terkadang jugamempersulit masyarakat baik itu untuk memperolehnya ataupun melegalisir dokumen tersebut, sehingga proses pengajuan dana santunan memakan prosesyang cukup lama.

Disaat semua berkas sudah lengkap dan telah diajukan oleh pihak korban atau ahli waris, masih ada kendala yang dihadapi dalam pengajuan berkas. Kendala tersebut dialami oleh pihak PT. Jasa Raharja selaku pemberi santunan. Salah satu kendala yang mungkin saja terjadi adalah hilang atau tercecernya berkas pengajuan santunan yang telah diberikan oleh korban atau ahli waris. Hilang atau tercecernya berkas bisa terjadi saat banyaknya berkas yang diajukan bisa terjadi saat proses memperbanyak berkas klaim (Fotokopi berkas). Seperti tertukarnya berkas korban A atau korban B. Walaupun kendala diatas jarang terjadi, namun jika terjadi maka akan memperlambat proses pemberian dana santunan asuransi kepada pihak korban atau ahli waris.

PT. Jasa Raharja (Persero) dalam melayani klaimnya tidak terlepas dari bantuan mitra kerjanya seperti, kepolisian lalu lintas memberikan bantuan tentang kecelakaan tersebut, mengenai tabrakan yang terjadi,tempat terjadinya laka lantas,jam terjadinya dan lokasi kejadian laka lantas, juga bantuan dari dokter pihak rumah sakit yang menanganinya yang memberikan penjelasan tentang sakit/luka-luka yang di derita oleh korban laka lantas tersebut sehingga dengan penjelasan tersebut dapat memudahkan dibagian klaim mengurus dana santunan asuransi kecelakaan lalu lintas tersebut.

Untuk mengatasi permasalahan diatas diperlukan sebuah prosedur yang baik. Mulai dari prosesnya sampai dokumen-dokumen yang digunakan harus benar. Sehingga prosedur dapat berjalan dengan baik, maka akan tercapailah visi dan misi perusahaan terkemuka dibidang asuransi denganmengutamakan penyelenggaraan program asuransi sosial.

\section{Rumusan Masalah}

Berdasarkan latar belakang diatas, maka penulis akan membuat rumusan masalah "Bagaimana prosedur pencairan dana santunan asuransi terhadap korban kecelakaan meninggal dunia pada PT. Jasa Raharja (Persero) Purwokerto?"

\section{Pembatasan Masalah}

Pada penulisan laporan Tugas Akhir ini, penulis membatasi permasalahan yang akan dibahas. Penulisan ini dibatasi hanya pada Prosedur Pencairan Dana Santunan Asuransi Kecelakaan Terhadap Korban Kecelakaan Meninggal Dunia Pada PT. Jasa Raharja (Persero) Purwokerto.

\section{Metode Pengumpulan Data}

a. Data Primer

Metode Pengumpulan Data yang diperoleh pada PT. Jasa Raharja (Persero) Purwokerto sebagai berikut:

\section{Metode Observasi}


Pengumpulan data sesuai dengan cara mengamati langsung pada obyek yang dituju serta melakukan pencataan terhadap hal-hal yang masih berhubungan dengan obyek tersebut.

\section{Metode Wawancara}

Pengumpulan data yang dilakukan dengan cara mengajukan tanya jawab langsung kepada karyawan PT. Jasa Raharja (Persero).

b. Data Sekunder

Yaitu data tambahan yang mendukung dalam penyusunan laporan kerja praktik. Data Sekunder dapat diperoleh melalui:

\section{Metode Dokumentasi}

Pengumpulan data yang diperoleh dari kantor Jasa Raharja(Persero) Purwokerto dengan cara melihat arsip yang disimpan disuatu media yang terdiri dari kumpulan karakter yang didokumentasikan.

\section{Studi Pustaka}

Menggunakan buku-buku yang berada dilingkungan praktik kerja lapangan (PKL) yang berhubungan dengan prosedur pada kantor Jasa Raharja (Persero) Purwokerto.

\section{TINJAUAN PUSTAKA}

\section{Prosedur}

\section{Pengertian Prosedur}

Prosedur ialah sebuah rangkaian aksi yang jelas atau dikatakan juga sebuah tindakan yang musti dilakukan dengan cara atau teknik yang sama dengan yang tertera pada sebuah teks prosedur, agar dapat menghasilkan hal yang sama. sebuah prosedur bisa juga sebagai rangkaian kegiatan atau tahap-tahap yang musti dijalankan agar dapat menghasilkan sesuatu yang di inginkan.

Pengertian prosedur menurut beberapa para ahli diantaranya:

a. Mulyadi (2016:4) "prosedur adalah suatu kegiatan klerikal, biasanya melibatkan beberapa orang dalam suatu departemen atau lebih, yang dibuat untuk menjamin penanganan secara seragam transaksi perusahaan yang terjadi berulang-ulang".

b. Rudi M (2013:84) "prosedur sebagai pedoman yang berisi prosedur operasional yang ada di dalam suatu organisasi yang digunakan untuk memastikan bahwa semua keputusan dan tindakan, sertapenggunaan fasilitas-fasilitas proses yang dilakukan oleh orang- orang didalam organisasi yang merupakan anggota organisasi berjalan efektif dan efisien, konsisten, standar dan sistematis".

RAAR

Vol.1 No.1

c. Ira Crisyanti (2011:43) "Prosedur adalah Tata cara kerja yaitu rangkaian tindakan, langkah atau perbuatan yang harus dilakukan oleh seseorang dan merupakan cara yang tetap untuk dapat mencapai tahap tertentu dalam hubungan mencapai tujuan akhir".

Berdasarkan pendapat dari beberapa ahli mengenai prosedur, maka penulis mengambil kesimpulan bahwa prosedur adalah suatu urutan langkah-langkah pemrosesan data atau urutan kegiatan yang melibatkan beberapa orang dalam satu departemen atau lebih yang dibuat 
untuk menjamin penanganan secara seragam terhadap suatu transaksi perusahaan yang terjadi berulang-ulang.

\section{Pengertian Sistem}

Pengertian Sistem menurut beberapa ahli diantaranya:

a. Menurut West Chruchman yang diambil dari buku krismiaji dalam bukunya Sistem Informasi Akuntansi (2015:1) sebuah sistem dapat didefinisikan sebagai serangkaian komponen yang dikoordinasikan untuk mencapai serangkaian tujuan.

b. Menurut Marshall B. Romney dan Paul John Steinbart dalam bukunya yang Accounting Information System (2014:3) sistem adalah serangkaian dua atau lebih komponen yang saling terkait dan berinteraksi untuk mencapai tujuan.

\section{Pelayanan Publik}

Pengertian Pelayanan Publik menurut beberapa para ahli diantaranya:

a. Pelayanan publik atau pelayanan umum dapat didefenisikan sebagai segala bentuk jasa pelayanan, baik dalam bentuk barang publik maupun jasa publik yang pada prinsipnya menjadi tanggung jawab dan dilaksanakan oleh instansi pemerintah di pusat, didaerah, dan dilingkungan Badan Usaha Milik Negara atau Badan Usaha Milik Daerah, dalam rangka upaya pemenuhan kebutuhan masyarakat maupun dalam rangka pelaksanaan ketentuan peraturan perundang-undangan (Ratminto dan Winarsih 2013:5).

b. Pelayanan publik (public service) adalah suatu pelayanan atau pemberian terhadap masyarakat yang berupa penggunaan fasilitas-fasilitas umum, baik jasa maupun non jasa yang dilakukan oleh organisasi publik dalam hal ini adalah suatu pemerintahan dalam ( Rohman, dkk 2010:3)

\section{Dana Santunan Asuransi Kecelakaan}

\section{Pengertian Dana Santunan Asuransi Kecelakaan}

Dana santunan asuransi di PT. Jasa Raharja (Persero) merupakan dana santunan yang berasal dari sumbangan wajib dan iuran wajib pengguna kendaraan umum dan kendaraan pribadi. Dana santunan tersebut mengacu pada 2 (dua) undang- undang peransuransian yang dikeluarkan oleh pemerintah, yaitu undang-undang No. 33 tahun 1964 tentang dana wajib kecelakan penumpang dan undang-undang No. 34 tahun 1964tentang dana pertanggungan wajib kecelakaan lalu lintas jalan.

\section{Unsur-Unsur Dalam Asuransi:}

Berdasarkan definisi tentang asuransi yang dikemukakan oleh berbagai sumber tersebut, maka di dalam asuransi terkandung beberapa unsur, di antaranya adalah:

a. Pihak tertanggung (insured), merupakan pihak yang menjadi obyek asuransi dan memiliki kewajiban untuk membayar uang premi kepada pihak penanggung secara sekaligus atau berangsur-angsur.

b. Pihak penanggung (insure), merupakan pihak yang bersediauntuk menanggung 
kerugian yang mungkin terjadi pada seseorang yang menjadi tanggungannya berdasarkan perjanjian yang telah disepakati. Pihak penanggung akan membayar sejumlah uang kepada pihak tertanggung secara langsung atau berangsur-angsur apabila terjadi sesuatu dikemudian hari.

c. Suatu peristiwa (accident), merupakan suatu peristiwa atau kejadian yang tidak tentu (tidak terduga sebelumnya).

d. Kepentingan (interest), yang mungkin akan mengalami kerugian karena peristiwa yang tidak tentu.

\section{Ahli Waris}

Masyarakat yang mengalami kecelakaan kecelakaan meninggal dunia maka yang menerima dana santunan asuransi adalah Ahli Waris korban. Berikut ini yang termasuk kedalam ahli waris korban adalah:

a. Ketentuan Ahli Waris

Santunan meninggal dunia diserahkan langsung kepada Ahli Wariskorban yang sah,yaitu:

1) Janda atau dudanya yang sah

2) Dalam hal tidak ada janda/dudanya, kepada anak-anaknya yangsah.

3) Dalam hal tidak ada janda/dudanya dan anak-anaknya yang sahkepada orang tua yang sah.

b. Disamakan kedudukannya dengan Anak dan Orang Tua yang sah.

1) Pengertian dari anak dan orang tua yang sah tidak selalu pengertian anak kandung dan orang tua kandung, akan tetapi anak tiri dan orang tua tiri disamakan kedudukannya sebagai Ahli Waris yang sah.

2) Demikian juga anak angkat dan orang tua angkat disamakan kedudukannya sebagai Ahli Waris yang sah apabila telah mendapat putusan dari Pengadilan Negeri atau Instansi yang berwenang.

\section{Prosedur Santunan Asuransi Kecelakaan}

\section{Pengertian Prosedur Santunan Asuransi Kecelakaan}

Proses pembayaran sejumlah uang baik tunai maupun non tunai dari pihak pembayar kepada pihak penerimanya melalui mekanisme prosedur asuransi kecelakaan, kesederhanaan dalam pelayanan santunan asuransi kecelakaan, ketepatan waktu dalam memberikan pelayanan atas santunan asuransi kecelakaan, responsibilitas petugas dalam memberikan layanan guna mewujudkan prosedur santunan yang baik yang dikeluarkan PT. Jasa Raharja (Persero) Purwokerto.

\section{RAAR}

Vol.1 No.1

\section{Prosedur Pencairan Dana Santunan}

Prosedur pencairan dana santunan atau klaim yang diterapkan oleh PT Jasa Raharja (Persero), yaitu sebagai berikut:

a. Prosedur Penerimaan Klaim 
i. Front Office menerima Dokumen Pengajuan Klaim Asuransi, Formulir Pengajuan Santunan, Keterangan Singkat Kejadian Kecelakaan dan Keterangan Ahli Waris dari Klaim.

ii. Front Office meneliti kelengkapan Dokumen Pengajuan Klaim Asuransi, Formulir Pengajuan Santunan, Keterangan Singkat Kejadian Kecelakaan dan Keterangan Ahli Waris dari Klaimen.

iii. Front Office memberikan Dokumen Pengajuan Klaim Asuransi, Formulir Pengajuan Santunan, Keterangan Singkat Kejadian Kecelakaan dan Keterangan Ahli Waris dari Klaimen tersebut ke bagian pelayanan.

b. Prosedur Pelayanan Klaim

i. Bagian Pelayanan melakukan pengecekan kembali kelengkapan Dokumen Pengajuan Klaim Asuransi, Formulir Pengajuan Santunan, Keterangan Singkat Kejadian Kecelakaan dan Keterangan Ahli Waris.

ii. Bagian Pelayanan meneliti keabsahan Dokumen Pengajuan Klaim Asuransi, Formulir Pengajuan Santunan, Keterangan Singkat Kejadian Kecelakaan dan Keterangan Ahli Waris dan kasus kecelakaan yang diterima dari bagian Front Office.

iii. Bagian Pelayanan memperoses administrasi penerimaan Dokumen Pengajuan Klaim Asuransi, Formulir Pengajuan Santunan, Keterangan Singkat Kejadian Kecelakaan danKeterangan Ahli Waris.

iv. Bagian Pelayanan menyerahkan kembali Dokumen Pengajuan Klaim Asuransi, Formulir Pengajuan Santunan, Keterangan Singkat Kejadian Kecelakaan dan Keterangan Ahli Waris kepada Klaim untuk difotocopy sebanyak 3 rangkap.

v. Bagian Pelayanan menerima kembali Dokumen Pengajuan Klaim Asuransi, Formulir Pengajuan Santunan, KeteranganSingkat Kejadian Kecelakaan dan Keterangan Ahli Waris dari Klaim yang telah diperbanyak.

vi. Bagian Pelayanan mengentry data Klaim ke dalam komputer dan membuat Tanda Terima Berkas (TTB) dan Lembar Disposisi Pengawal Berkas (LDPB).

vii. Bagian Pelayanan menyerahkan Dokumen Pengajuan Klaim Asuransi, Formulir Pengajuan Santunan, Keterangan Singkat Kejadian Kecelakaan dan Keterangan Ahli Waris serta TTB dan LDPB kepada Kepala Perwakilan.

viii. Bagian Pelayanan menyerahkan Dokumen Pengajuan Klaim Asuransi, Formulir Pengajuan Santunan, Keterangan Singkat Kejadian Kecelakaan dan Keterangan Ahli Waris serta TTB dan LDPB dari Kepala Perwakilan beserta perintah untuk dilakukannya suatu tindakan.

ix. Bagian Pelayanan melaksanakan perintah dari Kepala Perwakilan, perintah tersebut berisi bahwa:

1. Jika terjamin maka Bagian Pelayanan melakukan pengecekan domisili Klaimen, membuat janji ke Klaimen dan membuat Kuitansi Pembayaran Klaim.

2. Jika tidak terjamin dibuatkan Surat Penolakan kemudiandiberikan ke Klaimen. 
3. Jika domisili Klaimen diluar wilayah kerja PT Jasa Raharja (Persero) Perwakilan Purwokerto maka dibuatkan Surat Pelimpahan ke cabang atau perwakilan lainnya sesuai dengan domisili Klaimen.

4. Jika domisili didalam wilayah PT Jasa Raharja (Persero)Perwakilan Purwokerto maka Bagian Pelayanan melakukan cek keabsahan, jika sesuai maka Kepala Perwakilan menyerahkan Dokumen Pengajuan Klaim Asuransi kepada Bagian Pelayanan.

5. Jika tidak sesuai atau meragukan, diserahkan kepada Bagian Pelayanan untuk dilakukan survey baik ke Tempat Kejadian Perkara (TKP) maupun ke rumah korban, setelah melakukan survey Bagian Pelayananmembuat Laporan Hasil Survey (LHS).

x. Bagian Pelayanan memberikan Dokumen Pengajuan Klaim Asuransi, Formulir Pengajuan Santunan, Keterangan Singkat Kejadian Kecelakaan, Keterangan Ahli Waris, TTB, LDPB dan LHS serta Kuitansi Pembayaran Klaim ke PJ Keuangan.

c. Prosedur Pengesahan

i. Kepala Perwakilan menerima Dokumen Pengajuan Klaim Asuransi, Formulir Pengajuan Santunan, Keterangan Singkat Kejadian Kecelakaan dan Keterangan Ahli Waris serta TTB dan LDPB dari Bagian Pelayanan untuk menetapkan otorisasi terhadap berkas atau kasus kecelakaan.

ii. Kepala Perwakilan memberikan kembali Dokumen Pengajuan Klaim Asuransi, Formulir Pengajuan Santunan, Keterangan Singkat Kejadian Kecelakaan dan Keterangan Ahli Waris serta TTB dan LDPB ke Bagian Pelayanan beserta perintah untuk dilakukannya suatu tindakan.

iii. Kepala Perwakilan menerima Dokumen Pengajuan Klaim Asuransi, Formulir Pengajuan Santunan, Keterangan Singkat Kejadian Kecelakaan, Keterangan Ahli Waris, TTB, LDPB yang berisi pendapat atau petunjuk dan LHS serta Kuitansi Pembayaran Klaim dari PJ Keuangan.

iv. Kepala Perwakilan melakukan persetujuan atas pembayaran klaim asuransi kepada Klaimen.

v. Kepala Perwakilan memberikan Dokumen Pengajuan Klaim Asuransi, Formulir Pengajuan Santunan, Keterangan Singkat Kejadian Kecelakaan, Keterangan Ahli Waris, TTB, LDPB yang berisi pendapat atau petunjuk dan LHS serta Kuitansi Pembayaran Klaim ke Kasir.

vi. Kepala Perwakilan menerima Bukti Pengeluaran Kas yang telah ditandatangani PJ Keuangan, Surat Perintah Transfer dan Bilyet Giro dari Kasir, lalu mendatangani dokumen- dokumen tersebut kemudian dikembalikan ke Kasir untuk dilakukan pembayaran klaim asuransi ke Klaimen.

d. Prosedur Verifikasi

i. PJ Keuangan menerima Dokumen Pengajuan Klaim Asuransi, Formulir Pengajuan Santunan, Keterangan Singkat Kejadian Kecelakaan, Keterangan Ahli Waris, TTB, LDPB dan LHS serta Kuitansi Pembayaran Klaim dari Bagian Pelayanan.

ii. PJ Keuangan melakukan verifikasi terhadap kuitansi biaya- biaya dari Rumah Sakit 
dengan Kuitansi Pembayaran Klaim dan memberikan pendapat atau petunjuk padalembar Disposisi Pengawalan Berkas.

iii. PJ Keuangan membeikan Dokumen Pengajuan KlaimAsuransi, Formulir Pengajuan Santunan, Keterangan Singkat Kejadian Kecelakaan, Keterangan Ahli Waris, TTB, LDPB yang berisi pendapat atau petunjuk dan LHS serta Kuitansi Pembayaran Klaim ke Kepala Perwakilan untuk dilakukan persetujuan pembayaran klaim.

e. Prosedur pembayaran Klaim Asuransi

i. Kasir menerima Dokumen Pengajuan Klaim Asuransi, Formulir Pengajuan Santunan, Keterangan Singkat Kejadian Kecelakaan, Keterangan Ahli Waris, TTB, LDPB yang berisi pendapat atau petunjuk dan LHS serta Kuitansi Pembayaran Klaim dari Kepala Perwakilan.

ii. Kasir membuat Bukti Pengeluaran Kas dan secara otomatis jurnal tercatat pada saat Bukti Pengeluaran tercetak, Surat Perintah Transfer dan Bilyet Giro.

iii. Dokumen Pengajuan Klaim Asuransi, Formulir Pengajuan Santunan, Keterangan Singkat Kejadian Kecelakaan, Keterangan Ahli Waris, TTB, LDPB yang berisi pendapat atau petunjuk dan LHS serta Kuitansi Pembayaran Klaim yang diterima dari Kepala Perwakilan diarsip sementara berdasarkan nomor sambil menunggu Bukti Pengeluaran Kas, Surat Perintah Transfer dan Bilyet Giro ditandatangani Kepala Perwakilan.

iv. Kasir meminta tanda tangan Kepala Perwakilan sebagai otorisasi terhadap pembayaran klaim asuransi dengan memberikan Bukti Pengeluaran Kas, Surat Perintah Transfer dan Bilyet Giro ke Kepala Perwakilan.

v. Kasir menerima Bukti Pengeluaran Kas, Surat Perintah Transfer dan Bilyet Giro dari Kepala Perwakilan.

vi. Dokumen Pengajuan Klaim Asuransi, Formulir Pengajuan Santunan, Keterangan Singkat Kejadian Kecelakaan, Keterangan Ahli Waris, TTB, LDPB yang berisi pendapat atau petunjuk dan LHS serta Kuitansi Pembayaran Klaim yang diarsip sementara berdasarkan nomor dibuka kembali dan dijadikan satu dengan Bukti Pengeluaran Kas, Surat Perintah Transfer dan Bilyet Giro untuk dilakukan pembayaran.

vii. Kasir melakukan wawancara untuk memastikan kebenaran penerimaan santunan sebelum melakukan pembayaran klaim asuransi.

viii. Kasir mencocokan data yang ada di KTP klaimen sebelum penyerahan uang santunan, lalu meminta tanda tangan klaimen untuk Bukti Kas Keluar.

ix. Kasir melakukan pembayaran kepada klaimen jika pembayaran dilakukan secara tunai.

Sejarah PT.Jasa Raharja (Persero) Purwokerto 
Sejarah berdirinya Jasa Raharja tidak lepas dari kebijakan pemerintahuntuk melakukan nasionalisasi terhadap Perusahaan-perusahaan milik Belandadengan diundangkannya Undang-Undang No.86 tahun 1958 tentang NasionalisasiPerusahaan Belanda.

Penjabaran dari Undang-Undang tersebut dalam bidang asuransi kerugian, pemerintah melakukan nasionalisasi perusahaan-perusahaan asuransi kerugian Belanda berdasarkan Peraturan Pemerintah (PP) No.6 tahun 1960 tentang Penentuan Perusahaan Asuransi Kerugian Belanda yang dikenakan Nasionalisasi. Adapun perusahaan-perusahaan yang dinasionalisasi dimaksud sebagai berikut:

1. Perusahaan Firma Bekouw \& Mijnssen di Jakarta.

2. Perusahaan Firma Blom \& van Der Aa di Jakarta

3. Perusahaan Firma Sluyters di Jakarta.

Peraturan Pemerintah tersebut ditetapkan tanggal 16 Januari 1960, namun berlaku surut sampai tanggal 3 Desember 1957.

Selanjutnya, beberapa perusahaan yang telah dinasionalisasi tersebut ditetapkan dengan status badan hukum Perusahaan Negara Asuransi Kerugian (PNAK) sesuai dengan Undang-Undang Nomor 19 Pp Tahun 1960 tentang Perusahaan Negara yang seluruh modalnya merupakan kekayaan Negara RepublikIndonesia.

\section{Pada tahun 1961}

Berdasarkan Peraturan Pemerintah Nomor 15 Tahun 1961 tentang Pendirian Perusahaan Negara Asuransi Kerugian Eka Karya, keempat PNAK tersebut yang semula berdasarkan Pengumuman Menteri Keuangan (Badan Penguasa Perusahaanperusahaan Asuransi Kerugian Belanda) No.12631/B.U.M. tanggal 9 Februari 1960 yang nama perusahaannya disebut dengan "Ika" menjadi "Eka".

Berdasarkan Peraturan Pemerintah itu pula, keempat PNAK tersebut yaitu Eka Bhakti, Eka Dharma, Eka Mulya dan Eka Sakti pada tanggal 1 Januari 1961 dilebur untuk menjadi satu perusahaan dengan nama PNAK Eka Karya. Dengan peleburan tersebut, maka segala hak dan kewajiban, kekayaan, pegawai dan usaha keempat perusahaan tersebut beralih kepada PNAK Eka Karya. Namun dalam Pengumuman Menteri Keuangan (Badan Penguasa Perusahaan-perusahaan Asuransi Kerugian Belanda) No.: 29495\%/B.U.M.II tanggal 31 Desember 1960, penyebutan nama perusahaanperusahaan tersebut kembali menggunakan "Ika" termasuk perusahaan yang baru didirikan tersebut yaitu "Ika Karya". Adanya perbedaan tersebut disebabkan karena Pengumuman Menteri Keuangan tersebut diterbitkan mendahului diundangkannya Peraturan Pemerintah Nomor 15 Tahun 1961 tentang Pendirian Perusahaan Negara Asuransi Kerugian Eka Karya yaitu pada tanggal 24 Maret 1961.

PNAK Eka Karya yang berkedudukan dan berkantor pusat di Jakarta dan dapat mempunyai kantor cabang, kantor perwakilan, agen atau koresponden di dalam dan/atau di luar negeri, bergerak dalam bidang usaha perasuransian yaitu:

RAAR

Vol.1 No.1
1. Mengadakan dan menutup segala macam asuransi termasuk reasuransi, kecuali pertanggungan jiwa.

2. Memberi perantaraan dalam penutupan segala macam asuransi. 


\section{Pada tahun 1965}

Berdasarkan Peraturan Pemerintah No.8 tahun 1965 tentang Pendirian Perusahaan Negara Asuransi Kerugian Djasa Rahardja, mulai 1 Januari 1965 PNAK Eka Karya dilebur menjadi perusahaan baru dengan nama "Perusahaan Negara Asuransi Kerugian Jasa Raharja"dan seluruh kekayaan, pegawai dan segala hutang piutang PNAK Eka Karya dialihkan kepada PNAK Jasa Raharja. Sebagaimana PNAK Eka Karya, PNAK Jasa Raharja pun berkedudukan danberkantor pusat di Jakarta dan dapat mempunyai kantor cabang, kantor perwakilan, sedangkan untuk agen atau koresponden hanya diperkenankan didalam negeri.

Berbeda dengan PNAK Eka Karya yang memberikan pertanggungan yang bersifat umum untuk segala jenis asuransi, maka PNAK Jasa Raharja didirikan dengan kekhususan memberikan pertanggungan dalam bidang asuransi tanggung jawab kendaraan bermotor dan kecelakaan penumpang termasuk reasuransi dan perantaraan dalam bidang asuransi tanggung jawab kendaraan bermotor dan kecelakaan penumpang.

Beberapa bulan sejak pendirian PNAK Jasa Raharja, tepatnya tanggal 30 Maret 1965 Pemerintah menerbitkan Surat Keputusan Menteri Urusan Pendapatan, Pembiayaan dan Pengawasan No. B.A.P.N. 1-3-3 yang menunjuk PNAK Jasa Raharja untuk melaksanakan penyelenggaraan Dana Pertanggungan Wajib Kecelakaan Penumpang dan Dana Kecelakaan Lalu Lintas Jalan sesuai Undang-Undang Nomor 33 dan UndangUndang Nomor 34 tahun 1964.

\section{Pada tahun 1970}

Pada tahun 1970, PNAK Jasa Raharja diubah statusnya menjadi Perusahaan Umum (Perum) Jasa Raharja. Perubahan status ini dituangkan dalam Surat Keputusan Menteri Keuangan Republik Indonesia No. Kep.750/KMK/IV/II/1970 tanggal 18 November 1970, yang merupakan tindak lanjut dikeluarkannya Undang-Undang Nomor 9 tahun 1969 tentang Penetapan Peraturan Pemerintah Pengganti Undang-Undang Nomor 1 Tahun 1969 Tentang Bentuk-Bentuk Usaha Negara Menjadi Undang-Undang. Pasal 2 ayat 2 dari UU tersebut menyatakan bahwa PERUM adalah Perusahaan Negara yang didirikan dan diatur berdasarkan ketentuan-ketentuan yang termaktub dalam Undang Undang No. 19 Prp tahun 1960.

\section{Pada tahun 1978}

Pada tahun 1978 yaitu berdasarkan PP No.34 tahun 1978 tentang Perubahan Atas Peraturan Pemerintah Nomor 8 Tahun 1965 tentang Pendirian Perusahaan Umum Asuransi Kerugian "Jasa Raharja", selain mengelola pelaksanaan UU. No.33 dan UU. No. 34 tahun 1964, Jasa Raharja mendapat mandat tambahan untuk menerbitkan surat jaminan dalam bentuk Surety Bond. Penunjukan tersebut menjadikan Jasa Raharja sebagai pionir penyelenggara suretybond di Indonesia, di saat perusahaan asuransi lain umumnya masih bersifat fronting office dari perusahaan surety di luar negeri sehingga terjadi aliran devisa ke luar negeri untuk kepentingan tersebut.

Kemudian sebagai upaya pengemban rasa tanggung jawab sosial kepada masyarakat khususnya bagi mereka yang belum memperoleh perlindungan dalam lingkup UU No.33 dan UU No.34 tahun 1964, maka dikembangkan pula usaha Asuransi Aneka.

\section{Pada tahun 1980}

Kemudian dalam perkembangan selanjutnya, mengingat usaha yang ditangani oleh Perum Jasa Raharja semakin berkembang sehingga diperlukan pengelolaan usaha yang lebih terukur dan efisien, maka pada tahun 1980 berdasarkan PP No.39 tahun 1980 tentang Pengalihan Bentuk Perusahaan Umum Asuransi Kerugian "Jasa Raharja"

RAAR Vol.1 No.1 
menjadi Perusahaan Perseroan (Persero) tanggal 6 November 1980, status Jasa Raharja diubah lagi menjadi Perusahaan Perseroan (Persero) dengan nama PT (Persero) Asuransi Kerugian Jasa Raharja.

\section{Pada tahun 1981}

Anggaran Dasar Jasa Raharja yang semula diatur dalam Peraturan Pemerintah pendiriannya, maka sesuai dengan Peraturan Pemerintah No.12 tahun 1969 tentang Perusahaan Perseroan (PERSERO) pengaturannya harus dipisahkan. Anggaran Dasar Jasa Raharja tersebut selanjutnya dituangkan dalam Akte Notaris Imas Fatimah, SH No.49 tahun 1981 tanggal 28 Februari 1981.

Dengan adanya perubahan nomenklatur kementerian, pada tahun ini pula, Pemerintah melalui Menteri Keuangan memperbaharui penunjukan Jasa Raharja dengan menerbitkan Keputusan Menteri Keuangan No: 337/KMK.011/1981 tanggal 2 Juni 1981 tentang Penunjukan Perusahaan Perseroan (Persero) Asuransi Kerugian Jasa Raharja untuk Menyelenggarakan Dana Pertanggungan Wajib Kecelakaan Penumpang dan Dana Kecelakaan Lalu Lintas Jalan.

\section{Pada tahun 1994 - Sekarang}

Pada tahun 1994, pemerintah menetapkan Peraturan Pemerintah Nomor 73 Tahun 1992 tentang Penyelenggaraan Usaha Perasuransian sebagai penjabaran UU No.2 Tahun 1992 tentang Usaha Perasuransian. Peraturan Pemerintah tersebutmengatur antara lain ketentuan yang melarang Perusahaan Asuransi yang telah menyelenggarakan program asuransi sosial untuk menjalankan asuransi lain selainprogram asuransi sosial.

Sejalan dengan ketentuan tersebut, maka terhitung mulai tanggal 1 Januari 1994 hingga saat ini Jasa Raharja melepaskan usaha asuransi non wajib dan suretybond untuk lebih fokus dalam menjalankan program asuransi sosial yaitu menyelenggarakan Dana Pertanggungan Wajib Kecelakaan Penumpang sebagaimana diatur dalam UU. No.33 tahun 1964 dan Dana Kecelakaan Lalu Lintas Jalan sebagaimana diatur dalam UU. No.34 tahun 1964.

\section{Visi dan Misi PT. Jasa Raharja (Persero) Purwokerto}

a. Visi PT. Jasa Raharja (Persero) Purwokerto

"Menjadi perusahaan terkemuka di bidang Asuransi denganmengutamakan penyelenggaraan program Asuransi Sosial dan Asuransi Wajib sejalan dengan kebutuhan masyarakat".

b. Misi PT. Jasa Raharja (Persero) Purwokerto "Catur Bakti Eka Karsa Jasa Raharja”.

- Bakti Kepada Masyarakat

Dengan mengutakan perlindungan dasar dan pelayanan prima sejalan kebutuhan masyarakat.

- Bakti Kepada Negara

Dengan mewujudkan kinerja terbaik sebagai penyelenggara program Asuransi Sosial dan Asuransi Wajib serta Badan Usaha Milik Negara.

- Bakti Kepada Perusahaan Dengan mewujudkan keseimbangan kepentingan agar produktivitas dapat tercapai secara optimal demi kesinambungan perusahaan.

- Bakti Kepada Lingkungan 
Dengan memberdayakan potensi sumber daya bagi keseimbangan dan kelestarian lingkungan.

\section{Struktur Organisasi PT. Jasa Raharja (Persero) Purwokerto}

Struktur organisasi sangat penting bagi suatu organisasi atau perusahaan, dimana struktur tersebut menggambarkan dengan jelas tentang pembagian tugasnya atau pemisahan kegiatan pekerjaan antara masing- masing divisi atau bagian.

Adapun struktur organisasi PT. Jasa Raharja (Persero) Perwakilan Purwokerto yang terdiri dari Kepala Perwakilan, Bidang Teknik,Bidang Pelayanan Klaim, Bidang Keuangan \& Umum, Kasir, Penanggung Jawab Sistem Administrasi Manunggal Dibawah Satu Atap / PJ samsat sertadibantu oleh Pelaksana Administrasi.

\section{Uraian Tata Kerja}

Struktur organisasi merupakan pengorganisasian yang dilakukan agar proses penentuan, pengelompokan dan pengaturan macam-macam aktivitas yang diperlukan untuk mencapai tujuan dan menempatkan orang- orang pada setiap aktivitas, menetapkan wewenang yang secara relatif didelegasikan kepada setiap individu yang melaksanakan aktivitas tersebutsesuai dengan tugasnya.

Pencapaian tujuan secara maksimal di PT. Jasa Raharja (Persero), maka dibutuhkan kerjasama secara baik dan pembagian tugas pokok dan sasaran dari masing-masing unsur pendukungnya.

\section{PEMBAHASAN}

\section{Hasil Kegiatan Praktik Kerja Lapangan}

\section{Prosedur pencairan dana santunan atau klaim}

Dalam prosedur pencairan dana santunan PJ Pelayanan bertanggung jawab dalam tindakan proses pelayanan oleh klaimen. Dalam tindakan pelayanan klaim yang dilaksanakan oleh PT.Jasa Raharja (Persero) Purwokerto, telah dilakukan berdasarkan prosedur yang telah ditetapkan oleh PT.Jasa Raharja (Persero). Prosedur ini sangat berperan penting untuk memandu PJ Pelayanan dalam melaksanakan pelayanan pencairan dana santunan / klaim oleh klaimen. Dalam pelaksanaanya PT.Jasa Raharja (Persero) telah bekerjasama dengan kepolisisan lalu lintas guna memberikan informasi tentang kejadian kecelakaan lalu lintas juga bantuan dari rumah sakit yang menanganinya yang memberikan penjelasan tentang sakit/luka- luka yang di derita oleh korban laka lantas tersebut sehingga dengan penjelasan tersebut memudahkan dibagian pelayanan klaim mengurus dana santunan asuransi kecelakaan lalu lintas tersebut. Besaran dana santunan telah diatur oleh peraturan Menteri Keuangan RI Nomor.15/PMK.010/2017 dan 16/PMK.010/2017 Tanggal 13 Februari 2017 (kecelakaan tunggal tidak termasuk dalam tanggungan jasa raharja), Sebagai Berikut :

Tabel 1. Besaran Dana Santunan PT.Jasa Raharja (Persero)

\begin{tabular}{c|c|c}
\hline \multirow{2}{*}{ JENIS SANTUNAN } & \multicolumn{2}{|c}{ JENIS ALAT ANGKUTAN } \\
\cline { 2 - 3 } & $\begin{array}{c}\text { DARAT,LAUT } \\
(\mathrm{RP})\end{array}$ & UDARA (RP) \\
\hline Meninggal Dunia & Rp50.000.000 & Rp50.000.000 \\
\hline Cacat Tetap(Maksimal) & Rp50.000.000 & Rp50.000.000 \\
\hline Perawatan(Maksimal) & Rp20.000.000 & Rp25.000.000 \\
\hline
\end{tabular}




\begin{tabular}{c|c|c}
\hline $\begin{array}{c}\text { Penggantian Biaya } \\
\text { Penguburan (Tidak } \\
\text { Mempunyai Ahli Waris) }\end{array}$ & Rp4.000.000 & Rp4.000.000 \\
\hline $\begin{array}{c}\text { Manfaat Tambahan } \\
\text { Penggantian Biaya P3K }\end{array}$ & Rp1.000.000 & Rp1.000.000 \\
\hline $\begin{array}{c}\text { Manfaat Tambahan } \\
\text { Penggantian Biaya } \\
\text { Ambulance }\end{array}$ & & \\
\hline
\end{tabular}

Sumber $: \underline{w w w . j a s a r a h a r j a . c o . i d}$

Prosedur pencairan dana santunan atau klaim yang diterapkan olehPT Jasa Raharja (Persero), yaitu sebagai berikut:

1. Prosedur Penerimaan Klaim

a) Front Office menerima Dokumen Pengajuan Klaim Asuransi, Formulir Pengajuan Santunan, Keterangan Singkat Kejadian Kecelakaan dan Keterangan Ahli Waris dari Klaim.

b) Front Office meneliti kelengkapan Dokumen Pengajuan Klaim Asuransi, Formulir Pengajuan Santunan, Keterangan Singkat Kejadian Kecelakaan dan Keterangan Ahli Waris dari Klaimen.

c) Front Office memberikan Dokumen Pengajuan Klaim Asuransi, Formulir Pengajuan Santunan, Keterangan Singkat Kejadian Kecelakaan dan Keterangan Ahli Waris dari Klaimen tersebutke bagian pelayanan.

2. Prosedur Pelayanan Klaim

a) Bagian Pelayanan melakukan pengecekan kembali kelengkapan Dokumen Pengajuan Klaim Asuransi, Formulir Pengajuan Santunan, Keterangan Singkat Kejadian Kecelakaan dan Keterangan Ahli Waris.

b) Bagian Pelayanan meneliti keabsahan Dokumen Pengajuan Klaim Asuransi, Formulir Pengajuan Santunan, Keterangan Singkat Kejadian Kecelakaan dan Keterangan Ahli Waris dan kasus kecelakaan yang diterima dari bagian Front Office.

c) Bagian Pelayanan memperoses administrasi penerimaan Dokumen Pengajuan Klaim Asuransi, Formulir Pengajuan Santunan, Keterangan Singkat Kejadian Kecelakaan dan Keterangan Ahli Waris.

d) Bagian Pelayanan menyerahkan kembali Dokumen Pengajuan Klaim Asuransi, Formulir Pengajuan Santunan, Keterangan Singkat Kejadian Kecelakaan dan Keterangan Ahli Waris kepada Klaim untuk difotocopy sebanyak 3 rangkap.

e) Bagian Pelayanan menerima kembali Dokumen Pengajuan Klaim Asuransi, Formulir Pengajuan Santunan, Keterangan Singkat Kejadian Kecelakaan dan Keterangan Ahli Waris dari Klaim yang telah diperbanyak.

f) Bagian Pelayanan mengentry data Klaim ke dalam komputer dan membuat Tanda Terima Berkas (TTB) dan Lembar Disposisi Pengawal Berkas (LDPB).

g) Bagian Pelayanan menyerahkan Dokumen Pengajuan Klaim Asuransi, Formulir 
Pengajuan Santunan, Keterangan Singkat Kejadian Kecelakaan dan Keterangan Ahli Waris serta TTB dan LDPB kepada Kepala Perwakilan.

h) Bagian Pelayanan menyerahkan Dokumen Pengajuan Klaim Asuransi, Formulir Pengajuan Santunan, Keterangan Singkat Kejadian Kecelakaan dan Keterangan Ahli Waris serta TTB dan LDPB dari Kepala Perwakilan beserta perintah untuk dilakukannya suatu tindakan.

i) Bagian Pelayanan melaksanakan perintah dari Kepala Perwakilan, perintah tersebut berisi bahwa:

1) Jika terjamin maka Bagian Pelayanan melakukan pengecekan domisili Klaimen, membuat janji ke Klaimen dan membuat Kuitansi Pembayaran Klaim.

2) Jika tidak terjamin dibuatkan Surat Penolakan kemudian diberikan ke Klaimen.

3) Jika domisili Klaimen diluar wilayah kerja PT Jasa Raharja(Persero) Perwakilan Purwokerto maka dibuatkan Surat Pelimpahan ke cabang atau perwakilan lainnya sesuai dengan domisili Klaimen.

4) Jika domisili didalam wilayah PT Jasa Raharja (Persero) Perwakilan Purwokerto maka Bagian Pelayanan melakukan cek keabsahan, jika sesuai maka Kepala Perwakilan menyerahkan Dokumen Pengajuan Klaim Asuransi kepada Bagian Pelayanan.

5) Jika tidak sesuai atau meragukan, diserahkan kepada Bagian Pelayanan untuk dilakukan survey baik ke Tempat Kejadian Perkara (TKP) maupun ke rumah korban, setelah melakukan survey Bagian Pelayanan membuat Laporan Hasil Survey (LHS).

j) Bagian Pelayanan memberikan Dokumen Pengajuan Klaim Asuransi, Formulir Pengajuan Santunan, Keterangan Singkat Kejadian Kecelakaan, Keterangan Ahli Waris, TTB, LDPB dan LHS serta Kuitansi Pembayaran Klaim ke PJ Keuangan.

3. Prosedur Pengesahan

a) Kepala Perwakilan menerima Dokumen Pengajuan Klaim Asuransi, Formulir Pengajuan Santunan, Keterangan Singkat Kejadian Kecelakaan dan Keterangan Ahli Waris serta TTB dan LDPB dari Bagian Pelayanan untuk menetapkan otorisasi terhadap berkas atau kasus kecelakaan.

b) Kepala Perwakilan memberikan kembali Dokumen Pengajuan Klaim Asuransi, Formulir Pengajuan Santunan, Keterangan Singkat Kejadian Kecelakaan dan Keterangan Ahli Waris serta TTB dan LDPB ke Bagian Pelayanan beserta perintah untuk dilakukannya suatu tindakan.

c) Kepala Perwakilan menerima Dokumen Pengajuan Klaim Asuransi, Formulir Pengajuan Santunan, Keterangan Singkat Kejadian Kecelakaan, Keterangan Ahli Waris, TTB, LDPB yang berisi pendapat atau petunjuk dan LHS serta Kuitansi Pembayaran Klaim dari PJ Keuangan.

d) Kepala Perwakilan melakukan persetujuan atas pembayaran klaim asuransi kepada Klaimen. 
e) Kepala Perwakilan memberikan Dokumen Pengajuan Klaim Asuransi, Formulir Pengajuan Santunan, Keterangan Singkat Kejadian Kecelakaan, Keterangan Ahli Waris, TTB, LDPB yang berisi pendapat atau petunjuk dan LHS serta Kuitansi Pembayaran Klaim ke Kasir.

f) Kepala Perwakilan menerima Bukti Pengeluaran Kas yang telah ditandatangani PJ Keuangan , Surat Perintah Transfer dan Bilyet Giro dari Kasir, lalu mendatangani dokumen-dokumen tersebut kemudian dikembalikan ke Kasir untuk dilakukan pembayaran klaim asuransi ke Klaimen.

4. Prosedur Verifikasi

a) PJ Keuangan menerima Dokumen Pengajuan Klaim Asuransi, Formulir Pengajuan Santunan, Keterangan Singkat Kejadian Kecelakaan, Keterangan Ahli Waris, TTB, LDPB dan LHS sertaKuitansi Pembayaran Klaim dari Bagian Pelayanan.

b) PJ Keuangan melakukan verifikasi terhadap kuitansi biaya-biaya dari Rumah Sakit dengan Kuitansi Pembayaran Klaim dan memberikan pendapat atau petunjuk pada lembar Disposisi Pengawalan Berkas.

c) PJ Keuangan membeikan Dokumen Pengajuan Klaim Asuransi, Formulir Pengajuan Santunan, Keterangan Singkat Kejadian Kecelakaan, Keterangan Ahli Waris, TTB, LDPB yang berisi pendapat atau petunjuk dan LHS serta Kuitansi Pembayaran Klaim ke Kepala Perwakilan untuk dilakukan persetujuan pembayaran klaim.

5. Prosedur pembayaran Klaim Asuransi

a) Kasir menerima Dokumen Pengajuan Klaim Asuransi, Formulir Pengajuan Santunan, Keterangan Singkat Kejadian Kecelakaan, Keterangan Ahli Waris, TTB, LDPB yang berisi pendapat atau petunjuk dan LHS serta Kuitansi Pembayaran Klaim dari Kepala Perwakilan.

b) Kasir membuat Bukti Pengeluaran Kas dan secara otomatis jurnal tercatat pada saat Bukti Pengeluaran tercetak, Surat Perintah Transfer dan Bilyet Giro.

c) Dokumen Pengajuan Klaim Asuransi, Formulir Pengajuan Santunan, Keterangan Singkat Kejadian Kecelakaan, Keterangan Ahli Waris, TTB, LDPB yang berisi pendapat atau petunjuk dan LHS serta Kuitansi Pembayaran Klaim yang diterima dari Kepala Perwakilan diarsip sementara berdasarkan nomor sambil menunggu Bukti Pengeluaran Kas, Surat Perintah Transfer dan Bilyet Giro ditandatangani Kepala Perwakilan.

d) Kasir meminta tanda tangan Kepala Perwakilan sebagai otorisasiterhadap pembayaran klaim asuransi dengan memberikan Bukti Pengeluaran Kas, Surat Perintah Transfer dan Bilyet Giro ke Kepala Perwakilan.

e) Kasir menerima Bukti Pengeluaran Kas, Surat Perintah Transfer dan Bilyet Giro dari Kepala Perwakilan.

\section{RAAR}

Vol.1 No.1

f) Dokumen Pengajuan Klaim Asuransi, Formulir Pengajuan Santunan, Keterangan Singkat Kejadian Kecelakaan, Keterangan Ahli Waris, TTB, LDPB yang berisi pendapat atau petunjuk dan LHS serta Kuitansi Pembayaran Klaim yang diarsip sementara berdasarkan nomor dibuka kembali dan dijadikan satu dengan Bukti Pengeluaran Kas, Surat Perintah Transfer dan Bilyet Giro untuk dilakukan 
pembayaran.

g) Kasir melakukan wawancara untuk memastikan kebenaran penerimaan santunan sebelum melakukan pembayaran klaim asuransi.

h) Kasir mencocokan data yang ada di KTP klaimen sebelum penyerahan uang santunan, lalu meminta tanda tangan klaimen untuk Bukti Kas Keluar.

i) Kasir melakukan pembayaran kepada klaimen jika pembayaran dilakukan secara tunai.

\section{KESIMPULAN DAN SARAN}

\section{Kesimpulan}

Berdasarkan pembahasan diatas, dapat disimpulkan bahwa Prosedur pencairan dana santunan asuransi kecelakaan yang dilaksanakan oleh PT.Jasa Raharja (Persero) Purwokerto telahsesuai dengan Standart Operating Procedure (SOP) yang telah ditetapka oleh PT.Jasa Raharja (persero). Prosedur pencairan dana santunan asuransi kecelakaan telah menerapkan unsur-unsur dalam akuntansi yaitu Formulir pengajuan santunan, Jurnal, Surat perintah transfer (SPT), Bukti Kas Keluar (BKK) / Bukti transaksi agar memudahkan dalam pengelolaan perusahaan. PT.Jasa Raharja (Persero) juga telah melaksanakan beberapa elemen dalam suatu pengendalian intern yaitu adanya strukturorganisasi yang memisahkan tanggung jawab fungsional secara tegas dan mampu melaksanakan suatu sistem pembukuan yang baik yang dapat berguna bagi pengawasan terhadap harta milik perusahaan.

\section{Saran}

Kantor PT.Jasa Raharja (Persero) Purwokerto sebaiknya sering memberikan sosialisasi kepada seluruh elemen masyarakat terkait kesadaran terhadap tertib lalu lintas atau himbauan keamanan dalam berkendara yang bekerjasama dengan pihak kepolisisan lalu lintas guna meminimalisir angka kecelakaan lalu lintas yang bertujuan untuk mengurangi anggaran biaya pengeluaran dana santunan asuransi kecelakaan/klaim. PT.Jasa Raharja (Persero) Purwokerto sebaiknya membuat E- System Basis Data untuk membuat laporan ke cabang maupun pusat untuk meminimalisir penggunaan kertas yang berlebihan, jadi untuk berkas cukup 1 rangkap saja sehingga bisa menekan biaya pengeluaran untuk pembelian kertas. Dalam hal pencairan dana santunan bagi korban kecelakaan MD maupun luka-luka, diharapkan ada penyederhanaan dalam persyaratan dan prosedur agar lebih fleksibel, sehingga masyarakat mendapatkan pelayanan secara tepat waktu. Dalam hal kerjasama dengan instansi terkait, khususnya dengan pihak kepolisisan, perlu adanya peningkatan koordinasian sehingga kedua lembaga ini tidak terkesan berjalan sendiri-sendiri dalam hal penanganan korban kecelakaan lalu lintas. Koordinasi dengan pihak rumah sakit juga harus berjalan secara efektif dan efisien. Hal-hal yang bersifat prosedural perlu diminimalisir agar tidak menghambat upaya penanganan terhadap korban kecelakaan lalu lintas. Memberikan sosialisasi secara insentif melalui berbagai media sosial, sehingga masyarakat mengetahui hak dan kewajiban mereka tentang keberadaan PT.Jasa Raharja (Persero) dan peranan yang dijalankannya, demikian juga memberikansosialisasi terkait persyaratan yang diajukan untuk memperoleh dana santunan asuransi kecelakaan, serta memberikan gambaran mengenai asuransi yang dikelola oleh PT.Jasa Raharja (Persero), mengingat bahwa dana yang diberikan kepada para korban kecelakaan lalu lintas tersebut sesungguhnya berasal dari masyarakat yang dipungut dalam bentuk iuran dan sumbangan wajib. 


\section{REFERENSI}

65

Ainur Rohman, Ahmad \& dkk. (2010). Reformasi Pelayanan Publik Malang : Averroes Press

Dewi , Irra Chrisyanti. (2011). Pengantar Ilmu Administrasi, Jakarta : PT.Pustaka Raya

http//www.jasaraharja.co.id

Jasa Raharja. Undang-Undang No.33 "Tentang Dana Pertanggungan Wajib Kecelakaan Penumpang” \& Undang-Undang No.34 “ Tentang Dana Kecelakaan Lalu-Lintas Jalan” Tahun 1964

Krismiaji, (2015), Sistem Informasi Akuntansi, Yogyakarta : UPP STIM

YKPNMulyadi. (2016). Sistem Informasi Akuntansi. Jakarta : Salemba Empat

Peraturan Menteri Keuangan No.15/PMK.010/2017 “ Tentang Besar Santunan Dan Iuran Wajib Kecelakaan Penumpang Alat Angkutan Penumpang Umum di Darat, Sungai/Danau,Feri/Penyebrangan,Laut Dan Udara \& Peraturan Menteri Keuangan No.16/PMK.010/2017 “ Tentang Besar Santunan dan Sumbangan Wajib Dana Kecelakaan Lalu Lintas Jalan”

Ratminto \& Atik Septi Winasih. (2013). Manajemen Pelayanan. Yogyakarta : Pustaka Belajar Sitorus(2015:14)

Tambunan, Rudi M. (2013). Pedoman Penyusunan Standar Operating Procedures (SOP), Jakarta : Maistas Pulishing 